\title{
PENGARUH PENGGUNAAN PEMBELAJARAN KOOPERATIF TIPE STAD BERBANTUAN WINGEOM TERHADAP KEMAMPUAN PEMECAHAN MASALAH GEOMETRI SISWA SMA
}

\author{
Ikhsanudin \\ SMA Negeri 1 Marga Tiga Lampung Timur \\ ikhsanpps@gmail.com
}

\begin{abstract}
This research is a quasi-experimental with pre-test and post-test non-equivalent group design. The population in this research is all of the students on class X in SMA Negeri 1 Marga Tiga and the sampling technique is total sampling. Data are collected by documentation and test. Data are analyzed with descriptive statistics to compare the mean scores of $\mathrm{N}$-Gain obtained by each student. The results of the analysis shows that (1) the student's geometry problem solving ability with cooperative learning STAD is higher than the conventional learning, (2) the student's geometry problem solving ability with wingeom software in cooperative learning STAD is higher than the conventional learning, (3) the student's geometry problem solving ability with wingeom software in cooperative learning STAD is higher than without using wingeom software. This research shows that the cooperative learning STAD by using the wingeom software has a significant effect on the high school students' geometry problemsolving ability. The finding of this research shows that the students are still having difficulties in solving the problems, especially when the students have to look back whether the finishing is right or not.
\end{abstract}

Keywords: wingeom, geometry, STAD, problem solving

\section{PENDAHULUAN}

Hasil survei PISA

menyimpulkan bahwa prestasi matematika Indonesia pada tahun 2000, 2003, 2006 dan 2009 berada pada posisi di bawah rata-rata internasional. Selanjutnya menurut laporan dari Balitbang Kemendikbud pada tahun pelajaran 2011/2012 menunjukkan bahwa Standar Kompetensi Lulusan (SKL) tentang geometri berada pada posisi terendah, khususnya pada jenjang SMA dan hal ini pun terjadi di Provinsi Lampung.Selain itu berdasarkan laporan guru Matematika yang tergabung dalam MGMP (Musyawarah Guru Mata Pelajaran Matematika) SMA di Kabupaten Lampung Timur pada tahun pelajaran 2011/2012 menunjukkan bahwa prosentase ketuntasan materi ruang dimensi tiga berada pada posisi yang terendah. Sedangkan menurut Peraturan Menteri Pendidikan Nasional (permendiknas) nomor 23 tahun 2006 tentang Standar Kompetensi Lulusan (SKL) menyebutkan bahwa siswa harus mampu menentukan kedudukan, jarak dan besar sudut yang melibatkan titik, garis dan bidang di ruang dimensi tiga serta menggunakannya dalam pemecahan masalah. Berdasarkan keadaan ini, dapat dikatakan bahwa siswa ternyata masih mengalami kesulitan dalam mempelajari materi ruang dimensi tingga dan menggunakannya dalam pemecahan masalah. Selanjutnya Permendiknas nomor 22 tahun 2006 tentang standar isi menyebutkan bahwa pendekatan pemecahan masalah merupakan fokus dalam pembelajaran matematika yang mencakup masalah tertutup dengan 
solusi tunggal, masalah terbuka dengan solusi tidak tunggal, dan masalah dengan berbagai cara penyelesaian. Untuk membantu siswa dalam memahami materi ruang dimensi tiga dan menggunakannya dalam pemecahan masalah, diperlukan sebuah model pembelajaran dan media yang sesuai. Salah satu model pembelajarn yang dapat digunakan adalah model pembelajaran kooperatif tipe STAD dan penggunaan program komputer wingeom.

\section{Widyantini}

menyampaikan bahwa pembelajaran kooperatif tipe STAD merupakan pembelajaran kooperatif yang paling sederhana dan dapat digunakan untuk memberikan pemahaman konsep materi yang sulit kepada siswa dalam membelajarkan materi tersebut. Selanjutnya menurut penelitian dari Putra (2011) menyimpulkan bahwa pengunaan program wingeom mempunyai pengaruh yang cukup siginfikan dalam meningkatkan kemampuan analogi dan generalisasi matematis siswa pada materi geometri. Rahman (2012) dalam penelitiannya juga menyimpulkan bahwa penggunaan program wingeom memberikan pengaruh yang cukup signifikan terhadap peningkatan kemampuan spasial dan penalaran matematis siswa pada materi geometri.

Penelitian terhadap penggunaan model pembelajaran kooperatif STAD dan wingeom ini diharapkan dapat menjadi salah satu pilihan untuk mengatasi kesulitan siswa dalam pemecahan masalah pada materi ruang dimensi tiga, sehingganya akan dapat menjawab rumusan masalah (1) apakah kemampuan pemecahan masalah geometri siswa yang menggunakan pembelajaran kooperatif tipe STAD lebih tinggi dibandingkan dengan yang menggunakan pembelajaran konvensional? (2) apakah kemampuan pemecahan masalah geometri siswa yang menggunakan pembelajaran kooperatif tipe STAD berbantuan program wingeom lebih tinggi dibandingkan dengan yang menggunakan pembelajaran konvensional?(3) apakah kemampuan pemecahan masalah geometri siswa yang menggunakan pembelajaran kooperatif tipe STAD berbantuan program wingeom lebih tinggi dibandingkan dengan yang menggunakan pembelajaran kooperatif tipe STAD?

Penelitian ini bertujuan untuk:

1. Menganalisis perbedaan kemampuan pemecahan masalah geometri siswa pada pembelajaran konvensional dengan kooperatif tipe STAD.

2. Menganalisis perbedaan kemampuan pemecahan masalah geometri siswa pada pembelajaran konvensional dengan kooperatif tipe STAD dengan menggunakan program wingeom.

3. Menganalisis perbedaan kemampuan pemecahan masalah geometri siswa pada pembelajaran kooperatif tipe STAD dengan menggunakan program wingeom dan tanpa program wingeom. 
Pembelajaran kooperatif merupakan pembelajaran yang dapat menumbuhkan interaksi sosial. Menurut Vygotsky (Shadiq, 2008) menyatakan bahwa interaksi sosial merupakan salah satu faktor penting untuk memicu perkembangan kognitif seseorang. Pembelajaran kooperatif merupkan pembelajaran yang dapat digunakan untuk meningkatkan interaksi sosial, salah satunya adalah model pembelajaran kooperatif STAD. STAD (Student Team Achievement Division) atau Pembagian Pencapaian Tim Siswa adalah sebuah model pembelajaran kooperatif yang dikembangkan oleh Slavin. Menurut Slavin (Sutawidjaja dan Afgani D., 2011) menyebutkan bahwa STAD merupakan tipe cooperative learning yang paling sederhana dan paling mudah dipahami. Menurut situs wikipedia disebutkan bahwa STAD adalah sebuah model pembelajaran kooperatif yang terdiri dari kelompok kecil dengan beragam kemampuan untuk bekerja bersama untuk mencapai satu tujuan belajar yang sama. Menurut Sutawijaya dan Afgani D (2011) serta Setiawan (2008) langkah pada pembelajaran kooperatif STAD antara lain:

a. Siswa dikelompokkan menjadi kelompok-kelompok belajar yang terdiri dari 3 sampai 5 siswa berdasarkan kemampuan yang berbeda dari segi kemampuan, jenis kelamin dan kesukuan.

b. Guru menyajikan materi pelajaran secara klasikal.

c. Siswa belajar dalam kelompok masing-masing untuk penguatan materi, siswa saling membantu untuk mamahami dan menguasai materi pelajaran yang baru disampaikan guru.

d. Setiap siswa secara mandiri mengikuti tes atau kuis tentang materi pelajaran. e. Skor yang diperoleh setiap siswa dibandingkan dengan rata-rata skor sebelumnya kemudian dicari pertambahan nilainya. Skor dari setiap anggota kelompok dijumlahkan untuk memperoleh skor kelompok. Jumlah skor kelompok yang telah memenuhi kriteria akan diberi penghargaan berupa sertifikat ataupun hadiah yang lain.

Widyantini

(2008)

menyebutkan bawa karakter materimateri dalam standar isi yang dapat diajarkan dengan model STAD adalah:

1. Materi-materi untuk memahami konsep-konsep matematika yang sulit serta membutuhkan kemampuan bekerjasama, berpikir kritis, dan mengembangkan sikap sosial siswa;

2. Materi-materi yang berkaitan dengan pemecahan masalah (problem solving).

Menurut Ruseffendi (2010) soal pemecahan masalah adalah soal yang tidak rutin dan mempunyai prasyarat materi yang harus dikuasai terlebih dahulu serta belum diketahui penyelesaiannya. Menurut Polya (Badger, Trevor dan Sangwin : 2012, Setyabudhi: 2003) ada 4 langkah yang perlu dilakukan dalam menyelesaikan suatu masalah antara lain:

1) Understanding The Problem (Memahami masalah yang ada)

2) Devising A Plan (menyusun suatu strategi)

3) Carrying Out The Plan (melakukan strategi yang telah dipilih)

4) Looking Back (melihat kembali pekerjaan yang telah dilakukan)

Pembelajaran matematika di Indonesia saat ini mengacu pada 
Permendiknas nomor 22 tahun 2006 tentang standar isi yang secara implisit mencantumkan prosedur pemecahan masalah seperti yang disampaikan oleh Polya di atas. Untuk melihat apakah penyelesaian masalah yang dilakukan oleh siswa sudah sesuai dengan 4 langkah penyelesaian masalah yang dijadikan acuan, maka digunakanlah beberapa indikator pemecahan masalah berikut:

Tabel 1 Indikator Pemecahan Masalah

\begin{tabular}{|c|l|l|}
\hline No & Tahap Pemecahan Masalah & \multicolumn{1}{c|}{ Indikator } \\
\hline 1 & Memahami Masalah & $\begin{array}{l}\text { Siswa dapat menyebutkan, } \\
\text { menggambar berdasarkan informasi } \\
\text { dan pertanyaan yang ada }\end{array}$ \\
\hline 2 & $\begin{array}{l}\text { Menyusun Strategi } \\
\text { (Rencana) }\end{array}$ & $\begin{array}{l}\text { Siswa dapat membuat rencana } \\
\text { penyelesaian, menentukan pola, } \\
\text { membuat model, menentukan rumus } \\
\text { yang akan digunakan }\end{array}$ \\
\hline 3 & $\begin{array}{l}\text { Melaksanakan Strategi } \\
\text { (Rencana) }\end{array}$ & $\begin{array}{l}\text { Siswa melakukan langkah-langkah } \\
\text { penyelesaian sesuai rencana dengan } \\
\text { benar }\end{array}$ \\
\hline 4 & $\begin{array}{l}\text { Memeriksa Kembali yang } \\
\text { Telah dilakukan }\end{array}$ & $\begin{array}{l}\text { Siswa memeriksa kembali hasil } \\
\text { pekerjaannya dengan menggunakan } \\
\text { cara lain yang mungkin digunakan }\end{array}$ \\
\hline
\end{tabular}

Geometri diajarkan disetiap jenjang pendidikan karena geometri merupakan ruang lingkup matematika yang telah ada sejak manusia lahir. Hal ini sesuai dengan yang disampaikan oleh Afgani D (2011) bahwa geometri merupakan cabang matematika yang telah diakrabi manusia sejak lahir dan ada dimana-mana di setiap tempat dan hampir setiap objek visual. Secara khusus materi geometri SMA di sebutkan pada Standar Kompetensi (SK) ke 6 di kelas $\mathrm{X}$ yang kemudian dijabarkan dalam 3 Kompetensi Dasar (KD).

Wingeom adalah sebuah program komputer gratis yang termasuk dalam kategori dynamic geometry program yang dikembangkan oleh Philip Exeter University. Menurut Purnomo (2012) program wingeom dapat dijadikan sebagai mindtools (alat bantu berpikir) siswa, sehingga siswa dapat mengkonstruksi sendiri pengetahuannya
Selain itu menurut Rahman (2012) dalam penelitiannya menyimpulkan bahwa pembelajaran geometri dengan bantuan program wingeom memberikan pengaruh yang cukup signifikan terhadap kemampuan spasial dan penalaran matematika siswa. Rahman (2012) juga menyarankan agar dilakukan penelitian lebih lanjut untuk kemampuan matematis lain dalam pembelajaran menggunakan program ini. Menurut Lestari (2012) program ini dapat dimanfaatkan sebagai media pembelajaran matematika untuk mendemonstrasikan atau menvisualisasikan konsep-konsep matematika yang berhubungan dengan geometri.

Penggunaan model pembelajaran kooperatif STAD berbantuan program wingeom pada pembelajaran di kelas diharapkan dapat menjadi salah satu pilihan untuk membantu meningkatkan penguasaan materi geometri di SMA, 
sehingga hasilnya dapat sesuai dengan standar yang telah ditetapkan. Secara singkat konsep yang dikembangkan pada penelitian ini digambarkan pada gambar 1 berikut:

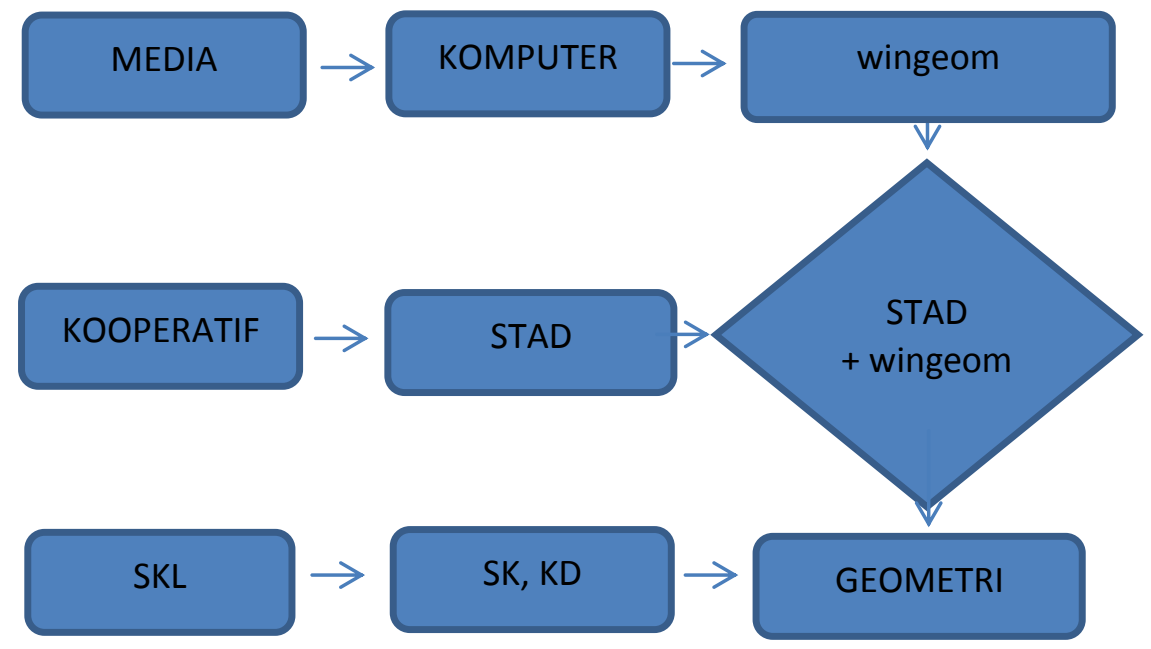

Gambar 1 Konsep Penelitian

\section{METODE PENELITIAN}

Penelitian ini merupakan penelitian eksperimen semu (kuasi) dengan menggunakan pre test and post test non equivalent group design (desain kelompok non-ekuivalen pretest dan post test). Secara visual bagan dari desain penelitian yang digunakan dapat digambarkan sebagai berikut:

\begin{tabular}{|cc|}
\hline & $\mathrm{O}_{1} \mathrm{X} \mathrm{O}_{2}$ \\
& $\mathrm{O}_{1} \mathrm{X}_{1} \mathrm{O}_{2}$ \\
& $\mathrm{O}_{1} \mathrm{X}_{2} \mathrm{O}_{2}$ \\
& \\
\hline $\mathrm{O}_{1} / \mathrm{O}_{2}$ & : Pre test /Post test \\
$\mathrm{X}$ & : Konvensional \\
$\mathrm{X}_{1}$ & : STAD \\
$\mathrm{X}_{2}$ & : STAD dengan wingeom \\
\hline
\end{tabular}

Gambar 2 Desain Penelitian
Populasi dalam penelitian ini adalah seluruh siswa kelas $X$ di SMA Negeri 1 Marga Tiga Kabupaten Lampung Timur, sedangkan sampelnya menggunakan sampel total yang sudah tersebar dalam 3 kelas yaitu kelas X.1, X.2 dan X.3 dengan jumlah siswa untuk setiap kelasnya dapat dilihat pada tabel 2. Penentuan kelas eksperimen dilakukan dengan pengundian, dan terpilihlah kelas X.1 menggunakan pembelajaran kooperatif STAD, X.2 menggunakan pembelajaran konvensional serta X.3 menggunakan pembelajaran kooperatif STAD dengan program wingeom.

Tabel 2 Jumlah Siswa Kelas X

\begin{tabular}{|c|c|c|}
\hline NO & Kelas & Jumlah Siswa \\
\hline 1 & X.1 & 30 \\
\hline 2 & X.2 & 30 \\
\hline 3 & X.3 & 30 \\
\hline
\end{tabular}

Sumber: Data Mutasi Siswa SMA

Negeri 1 Marga Tiga Pada Maret 2013

Pengumpulan data dilakukan dengan metode dokumentasi dan tes. Metode dokumentasi digunakan untuk mengumpulkan data pendukung 
penelitian seperti hasil survei PISA, laporan daya serap UN, laporan ketuntasan belajar matematika di kelas $\mathrm{X}$ serta data pendukung lainnya. Metode tes digunakan untuk mengukur pengaruh pembelajaran yang dilakukan pada masing-masing kelas. Tes yang digunakan berbentuk uraian berjumlah 3 soal untuk soal pretes maupun postes. Selanjutnya hasil pretes dan postes dihitung skor $n$-gain-nya dengan rumus:

$$
n-\text { gain }=\frac{\text { Skor Postes }- \text { Skor Pretes }}{\text { Skor Maksimum }- \text { Skor Pretes }}
$$

Karena sampel yang digunakan adalah sampel total, maka skor tersebut dianalisis dengan menggunakan statistik deskriptif yaitu dengan cara membandingkan skor rata-rata yang diperoleh masing-masing kelas.

\section{HASIL DAN PEMBAHASAN}

\section{Hasil Penelitian}

Skor n-gain pretes dan postes yang diperoleh pada penelitian ini secara garis besar disajikan pada tabel berikut ini:

Tabel 3 Perolehan $\mathrm{N}$-Gain Penelitian

\begin{tabular}{|c|l|c|c|c|}
\hline No & Deskripsi Statistik & $\begin{array}{c}\text { Kelas } \\
\text { Konvensional }\end{array}$ & $\begin{array}{c}\text { Kelas } \\
\text { STAD }\end{array}$ & $\begin{array}{c}\text { Kelas STAD } \\
\text { dengan } \\
\text { wingeom }\end{array}$ \\
\hline 1 & Jumlah siswa & 30 & 30 & 30 \\
\hline 2 & Rata-rata & 0,58 & 0,62 & 0,67 \\
\hline 3 & Standar Deviasi & 0,05 & 0,07 & 0,06 \\
\hline 4 & N-Gain Terendah & 0,46 & 0,42 & 0,57 \\
\hline 5 & N-Gain Tertinggi & 0,69 & 0,75 & 0,79 \\
\hline
\end{tabular}

Sumber: Data Penelitian

Dari Tabel 3, terlihat bahwa skor $n$-gain siswa pada kelas yang menggunakan model pembelajaran kooperatif STAD dengan bantuan wingeom lebih tinggi dibandingkan dengan perolehan skor $n$ gain dua kelas yang lainnya.

\section{Pembahasan Hasil Penelitian}

Penelitian ini menunjukkan bahwa model pembelajaran kooperatif STAD memberikan pengaruh yang cukup signifikan terhadap perbedaan rata-rata nilai siswa. Hasil analisis data menunjukkan bahwa rata-rata skor pemecahan masalah geometri siswa antara model pembelajaran kooperatif STAD dan konvensional memberikan perbedaan nilai yang cukup signifikan. Dengan pembelajaran kooperatif STAD, siswa dapat lebih banyak berinteraksi dengan siswa yang lain maupun dengan guru. Karena lebih banyak terjadi interaksi antara siswa dengan siswa serta guru maka pengalaman belajarnya akan lebih banyak dan berkesan, sehingga kemampuan yang dipelajari akan semakin bertambah. Hal ini sesuai dengan pendapat dari Vygotsky (Shadiq, 2008) yang menyatakan bahwa interaksi sosial yaitu interaksi individu dengan orang lain merupakan salah satu faktor penting untuk memicu perkembangan kognitif seseorang.

Selain itu, model pembelajaran kooperatif STAD dengan bantuan program wingeom menunjukkan perbedaan yang cukup signifikan terhadap skor rata-rata pencapaian kemampuan pemecahan masalah geometri siswa dengan kelas konvensional maupun dengan kelas yang menggunakan pembelajaran kooperatif STAD dengan bantuan program wingeom. Melihat hasil 
tersebut berarti dapat dikatakan bahwa rata-rata skor pencapaian kemampuan pemecahan masalah geometri siswa pada kelas yang menggunakan pembelajaran kooperatif STAD dengan bantuan program wingeom lebih tinggi dibandingkan dengan rata-rata skor pencapaian kemampuan masalah geometri siswa pada kelas konvensional, maupun dengan dengan kelas dengan model pembelajaran kooperatif STAD tanpa menggunakan program wingeom.

Dengan hasil yang demikian, pembelajaran kooperatif STAD dengan bantuan program wingeom dapat dipertimbangkan sebagai salah satu pilihan dalam rangka meningkatkan kemampuan pemecahan masalah matematika siswa di bidang geometri. Penggunaan program wingeom pada pembelajaran geometri dimensi tiga dapat mempermudah guru dalam menyajikan materi kepada siswa, karena dengan program ini guru tidak akan mengalami kesulitan dalam menggambar bangun dimensi tiga, dengan demikian guru lebih mudah membuat berbagai dokumen siap pakai dalam proses pembelajarannya. Selain itu guru dapat merancang gambar yang dapat digunakan secara interaktif oleh siswa sehingga siswa lebih tertarik untuk berekplorasi.

Penggunaan perangkat lunak komputer dalam pembelajaran matematika di sekolah-sekolah kita saat ini masih hal yang belum biasa, hal ini sesuai dengan yang disampaikan oleh Afgani D (2011) bahwa penggunaan komputer dalam pembelajaran di Indonesia masih belum banyak digunakan. Kesulitan tentunya ditemui dalam implementasinya, salah satu solusinya adalah menerapkan model pembelajaran kooperatif STAD dan dikolaborasikan dengan penggunaan teknologi komputer. Dengan model pembelajaran kooperatif STAD siswa yang mengalami kesulitan akan dapat dibantu oleh siswa lain yang telah menguasi materi yang dipelajari maupun penguasaan program komputer yang digunakan. Hal ini sesuai dengan beberapa penelitian yang telah dilakukan, diantaranya yang dilakukan oleh Irhamna dan Sutrisni (2012) yang menyimpulkan bahwa cooperative learning model STAD mampu meningkatkan prestasi belajar dan pemahaman siswa dalam bidang studi matematika. Selain itu menurut hasil penelitian dari Rahman (2012) yang menyimpulkan bahwa pembelajaran dengan bantuan program wingeom memberikan peningkatan terhadap hasil belajar siswa dengan cukup signifikan, hal ini juga sejalan dengan pendapat dari Purnomo (2012) yang menyatakan bahwa wingeom dapat dijadikan sebagai alat bantu berpikir dalam pembelajaran geometri.

Berdasarkan analisis terhadap perbedaan pencapaian skor rata-rata kemampuan pemecahan masalah geometri siswa terhadap tiga kelas pada penelitian ini, menunjukkan bahwa penggunaan model pembelajaran kooperatif STAD berpengaruh terhadap penguasaan kemampuan pemecahan masalah geometri siswa, selain itu pengaruh yang lebih besar diberikan pada pembelajaran kooperatif STAD dengan bantuan program wingeom. Menurut Polya dalam menyelesaian masalah menggunakan empat langkah yaitu: memahami soal, membuat perencanaan untuk penyelesaiannya, melaksanakan rencana yang telah dibuat serta melihat kembali apakah penyelesaian tersebut sudah benar atau belum. Untuk mempermudah apakah keempat langkah penyelesaian pemecahan masalah dapat dilakukan oleh masing-masing siswa, maka 
padalembar jawaban baik pada pretes maupun postes pada penelitian ini disediakan tempat untuk keempat langkah tersebut.

Empat langkah penyelesaian pemecahan masalah tersebut ternyata pada masing-masing kelas belum ada yang mampu menggunakannya secara keseluruhan, hal ini terbukti dengan hasil postes yang menunjukkan bahwa pada masing-masing kelas ternyata tidak ada yang memperoleh skor maksimal sebesar 15. Setelah dilakukan pengamatan terhadap lembar jawaban siswa yang memperoleh skor tertinggi ternyata pada langkah keempat yaitu melihat kembali apakah jawaban yang telah diselesaikan benar atau tidak, ratarata belum dapat diselesaikan. Setelah dilakukan diskusi dengan beberapa siswa, diperoleh informasi bahwa mereka secara umum belum biasa dengan cara penyelesaian yang seperti itu. Mereka cenderung senang dengan cara yang singkat dibandingkan dengan cara yang panjang seperti langkah penyelesaian masalah yang disediakan pada lembar jawaban. Siswa yang belajar dengan bantuan program wingeom cenderung lebih senang memeriksa kembali hasil pekerjaannya dengan menggunakan program ini. Dengan langkah-langkah yang harus meraka lalui ini sangat mungkin terjadi kesalahan. Hal ini sebagaimana telah disampaikan oleh Polya (1973) bahwa kesalahan selalu mungkin terjadi, terutama jika penyelesaian melibatkan cara-cara yang begitu panjang sehingga diperlukan verifikasi pada prosedurprosedur yang telah dilaluinya.

\section{KESIMPULAN DAN SARAN}

Berdasarkan hasil penelitian dan pembahasan tentang pengaruh penggunaan program wingeom pada pembelajaran kooperatif STAD terhadap kemampuan pemecahan masalah dimensi tiga siswa SMA, maka dapat diambil kesimpulan sebagai berikut:

1. Kemampuan pemecahan masalah geometri siswa yang menggunakan pembelajaran kooperatif tipe STAD lebih tinggi dibandingkan dengan yang menggunakan pembelajaran konvensional.

2. Kemampuan pemecahan masalah geometri siswa yang menggunakan pembelajaran kooperatif tipe STAD berbantuan program wingeom lebih tinggi dibandingkan dengan yang menggunakan pembelajaran konvensional.

3. Kemampuan pemecahan masalah geometri siswa yang menggunakan pembelajaran kooperatif tipe STAD berbantuan program wingeom lebih tinggi dibandingkan dengan yang menggunakan pembelajaran kooperatif tipe STAD tanpa bantuan program wingeom.

Berdasarkan pembahasan dan kesimpulan dapat disampaikan saransaran berikut:

1. Untuk guru mata pelajaran matematika:

a. Penelitian ini menunjukkan bahwa pembelajaran kooperatif STAD dengan bantuan program wingeom dapat meningkatkan kemampuan pemecahan masalah di bidang geometri, sehingga pembelajaran model ini dapat dijadikan alternatif untuk 
pembelajaran matematika dengan materi pokok geometri.

b. Penyelesaian soal dengan prosedur pemecahan masalah sebaiknya selalu dilatihkan kepada siswa, agar siswa terbiasa dan dapat menggunakannya dalam menyelesaikan soal-soal matematika dengan baik.

2. Untuk siswa:

a. Program wingeom dapat digunakan sebagai alat bantu untuk mempelajari geometri.

b. Agar kemampuan pemecahan masalah geometri menjadi lebih baik, penggunaan program wingeom harus didukung dengan kemampuan matematika di bidang yang lain seperti aljabar dan trigonometri.

3. Agar sekolah dapat menyediakan laboratorium komputer sebagai sarana pembelajaran matematika berbasis tekhnologi.

4. Kepada peneliti yang lain, kiranya dapat melakukan penelitian tentang pengaruh penggunaan program wingeom terhadap kemampuan pemecahan masalah geometri siswa jika setiap siswa dapat menggunakan alat bantu ini secara mandiri (bukan kooperatif).

\section{DAFTAR PUSTAKA}

Afgani D, Jarnawi. (2011). Analisis Kurikulum Matematika. Jakarta: Universitas Terbuka

Balitbang, Kemdikbud. (2011). Survei Internasional PISA. Diambil 02 Oktober
2012 dari situs World Wide

Web

http://litbang.kemdikbud.go.id/ index.php/survei-internasionalpisa

Balitbang, Kemdikbud. (2012). Laporan Hasil Ujian Nasional. Diambil 02 Januari 2013 dari situs World Wide Web http://118.98.234.22/ $\underline{\text { sekretariat/hasilun/ }}$

Badger, M., Sangwin, C. \& Hawkes, T.(2012). Teaching ProblemSolving in Undergraduate Mathematics. University of Birmingham

Depdiknas. (2006). Peraturan Menteri Nomor 22 tahun 2006 tentang Standar Isi untuk Satuan Pendidikan Dasar dan Menengah. Jakarta

Depdiknas. (2006). Peraturan Menteri Nomor 23 tahun 2006 tentang Standar Kompetensi Lulusan untuk Satuan Pendidikan Dasar dan Menengah . Jakarta

Irhamna, Mega dan Sutrisni (2012). Cooperative Learning dengan Model STAD pada

Pembelajaran Matematika Kelas VIII SMP Negeri 2 Delitua. Diambil 12 September 2012 dari situs World Wide Web http://lemlit.um.ac.id/wpcontent/uploads/2009/07/94.pdf

Polya, G. (1973). How to Solve It. New Jersey: Princeton University Press

Putra, H. (2011). Pembelajaran Geometri Dengan Pendekatan Savi Berbantuan Wingeom 
ISSN 2442-5419 Vol. 3, No. 1 (2014) 40-49

Untuk Meningkatkan

Kemampuan Analogi Dan

Generalisasi Matematis Siswa

SMP. Universitas Pendidikan

Indonesia: Tesis Tidak

diterbitkan

Rahman, B. (2012). Pembelajaran Matematika dengan wingeom untuk Meningkatkan

Kemampuan Spasial dan Penalaran Matematis Siswa. Universitas Pendidikan Indonesia: Tesis Tidak diterbitkan

Ruseffendi, H.(2010). Perkembangan Pendidikan Matematika.Jakarta: Universitas Terbuka

Setiawan. (2008). Strategi Pembelajaran Matematika SMA. Yogyakarta:

P4TK Matematika

Setyabudhi, W.(2003). Langkah Awal Menuju Ke Olimpiade Matematika. Jakarta: Ricardo

Shadiq, F. (2008). Psikologi Pembelajaran Matematika di SMA. Yogyakarta: P4TK

Matematika

Sutawijaya, A., Afgani D, J.(2011). Pembelajaran Matematika. Jakarta: Universitas Terbuka

Purnomo, J. (2012). Membuat File Pembelajaran Dinamis dengan Wingeom. Diambil 7

September 2012, dari situs World Wide Web http://p4tkmatematika.org/file/ ARTIKEL/Artikel\%20Teknolog i/Pembelajaran\%20dengan\%20 WINGEOM.pdf
Widyantini, T. (2008). Penerapan Pendekatan Kooperatif STAD dalam Pembelajaran Matematika di SMP. Yogyakarta: P4TK Matematika

Wikipedia. (2012). Student Team Achievement Division. Diambil 02 Oktober 2012, dari situs World Wide Web http://en.wikipedia.org/wiki/Stu dent Team

Achievement_Division 